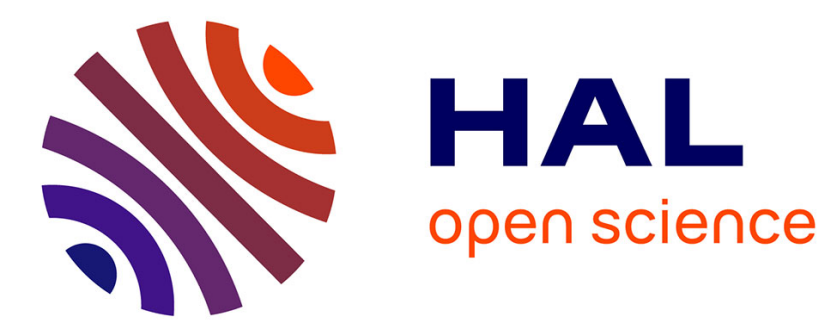

\title{
Paternal age $\geq 40$ years: an important risk factor for infertility
}

Elise de La Rochebrochard, Patrick Thonneau

\section{To cite this version:}

Elise de La Rochebrochard, Patrick Thonneau. Paternal age $\geq 40$ years: an important risk factor for infertility. American Journal of Obstetrics and Gynecology, 2003, 189 (4), pp.901 - 905. 10.1067/s0002-9378(03)00753-1 . hal-02264913

\section{HAL Id: hal-02264913 \\ https://hal.science/hal-02264913}

Submitted on 7 Aug 2019

HAL is a multi-disciplinary open access archive for the deposit and dissemination of scientific research documents, whether they are published or not. The documents may come from teaching and research institutions in France or abroad, or from public or private research centers.
L'archive ouverte pluridisciplinaire HAL, est destinée au dépôt et à la diffusion de documents scientifiques de niveau recherche, publiés ou non, émanant des établissements d'enseignement et de recherche français ou étrangers, des laboratoires publics ou privés. 
La Rochebrochard Elise (de), Thonneau Patrick, 2003, "Paternal age $\geq 40$ years: an important risk factor for infertility”. American Journal of Obstetrics and Gynecology, 189(4), p. 901905. DOI: $10.1067 / \mathrm{s} 0002-9378(03) 00753-1$

\section{Paternal age $\geq 40$ years: an important risk factor for infertility}

Elise de La Rochebrochard, PhD, INSERM (Institut National de la Santé et de la Recherche Médicale), Unit 569, 94275 Le Kremlin-Bicêtre, France, rochebro@ vjf.inserm.fr

Patrick Thonneau, MD, MSc Gynecol-Obstet, From Institut National de la Santé et de la Recherche Médicalea and the Human Fertility Research Group, INSERM, Paule de Viguier Hospital, thonneau.p@chu-toulouse.fr

CORRESPONDENCE AND REPRINT REQUESTS TO: Dr P. Thonneau, Human Human Fertility Research Group, Paule de Viguier Hospital, 330 avenue de Grande Bretagne, TSA 70034, 31059 Toulouse cedex 9, France, telephone: 335617780 25; fax: 335617778 43; e-mail: thonneau.p@ chu-toulouse.fr.

CONDENSATION: Risks of delay in pregnancy onset and of difficulties in having a baby increased with paternal age of $\geq 40$ years in a large European database. 


\begin{abstract}
Objective: To examine the risk of infertility associated with paternal age, as this factor has rarely been investigated, whereas maternal age of $\geq 35$ years is a well-known risk factor.

Study design: This large, retrospective, population-based sample included 6,188 European women (from Denmark, Italy, Spain, Germany) aged 25 to 44 years randomly selected from census registers in 1991-1993.

Results: Among couples composed of a woman aged 35-39 years, risks were significantly higher when paternal age was $\geq 40$ years than when paternal age was $<40$ years with an adjusted OR of $2.21(1.13,4.33)$ for delay in pregnancy onset (failure to conceive within 12 months) and of $3.02(1.56,5.85)$ for difficulties in having a baby (failure to conceive within 12 months or pregnancy not resulting in a live birth).
\end{abstract}

Conclusion: Like maternal age of $\geq 35$ years, paternal age of $\geq 40$ years should be considered as a key risk factor for infertility.

Key words: paternal age, maternal age, infertility 


\section{INTRODUCTION}

In industrialized countries, the proportion of women delaying pregnancy beyond the age of 35 years has greatly increased in recent decades. Women involved in in vitro fertilization (IVF) programs are also more frequently older than 35 . However, women deciding to have children after 35 have a higher risk of infertility. ${ }^{\mathbf{1 - 2}}$ Thus, it is important to identify the risk factors faced by couples in which the woman is older than 35 .

The possibility that paternal age may have an effect has rarely been considered. A few studies have concluded that paternal age affects the risks of infertility and of adverse pregnancy outcome such as miscarriage and late fetal death. ${ }^{3-5}$ A recent European multicenter study conducted on a large cohort of couples $(n=782)$ using natural family planning methods to avoid pregnancy showed that paternal age affects the probability of conception. ${ }^{6}$ However, another study analyzing success rates in 558 IVF cycles with donated oocytes found no paternal age effect. ${ }^{7}$

We investigated the possible effects of paternal age on infertility by analyzing a large European database. 


\section{MATERIALS AND METHODS}

Between 1991 and 1993, 6,188 women aged 25 to 44 years were randomly selected from census registers in Denmark, Italy, Spain and Germany, and retrospectively interviewed by trained women in a personal interview lasting 30-90 min. Questions were on their reproductive history (pregnancies, time to pregnancy, contraception, infertility, medical consultations) and sociodemographic, lifestyle and professional characteristics of the woman and her male partner. We excluded women who had never tried to conceive $(n=1,369)$, whose last pregnancy was unplanned $(\mathrm{n}=1,193)$, or who started trying to conceive in the year preceding the interview because delay of conception $\geq 12$ months could not be assessed in these women $(n=267)$. We also excluded observations with missing data $(n=72)$. Finally, 3,287 couples were selected and we analyzed the length of time for which the couple had been having intercourse without taking measures to prevent conception and the outcome of their last pregnancy.

To investigate human reproduction, most epidemiological research relies on measures of 'time to pregnancy' (TTP), defined as the number of noncontracepting menstrual cycles that it takes a couple to conceive. ${ }^{8-9}$ An increase in the TTP could reflect an alteration in either the male or female gametes (gametogenesis, transport of the gametes, fertilization) or the embryo (migration to the uterus, implantation, early survival). Thus, TTP appeared as a potentially sensitive tool to investigate reproductive hazards. Moreover, estimation of power curves of TTP showed that small sample sizes are sufficient for investigating reproductive risk factors. ${ }^{10}$ Based on measure of the TTP, we defined infertility as $\geq 12$ months of unsuccessful attempts to conceive by considering not only couples that finally conceived, but also couples that did not conceive or that gave up trying. In order to explore not only pregnancy occurrence but also the entire reproductive process, we considered two indicators of infertility: (i) risk of delay in pregnancy onset (no conception after 12 months), (ii) risk of difficulties in having a 
baby (no conception after 12 months or adverse pregnancy outcome, i.e. ectopic pregnancy, miscarrige or stillbirth).

To analyze paternal age, we compared men aged $\geq 40$ years with men aged $<40$ years in accordance with the literature, which indicated a paternal age effect after 40 years. ${ }^{6,11}$ As maternal age is highly correlated with paternal age, we controlled for maternal age by considering four groups: <30 years, 30-34 years, 35-39 years, $\geq 40$ years.

We investigated the paternal age effect in logistic multivariate models by estimating adjusted odds ratio (OR) on potential confounders presented in table I (countries, number of previous pregnancies, female smoking, male smoking, sexual activity, history of miscarriage, history of induced abortion). First, we analyzed the paternal age effect in the different maternal age groups. We then analyzed paternal age and maternal age together. 


\section{RESULTS}

We calculated the odds ratios for risk of infertility in the different maternal age groups after adjustment for potential confounders (Table II). Among couples in which the woman was aged <30 years or 30-34 years, risk of infertility was not significantly increased when the male partner was aged $\geq 40$ years. Among couples in which the woman was aged 35-39 years, the risk of delay in pregnancy onset and risk of difficulties in having a baby were significantly higher when the male partner was aged $\geq 40$ years than when the male partner was aged $<40$ years. We could not investigate the paternal age effect in couples composed of a woman aged $\geq 40$ years because there were too few observations in our database.

We then investigated the age effect by considering maternal age, paternal age or both (Table III). When considering only maternal age, we observed that the risk of delay in pregnancy onset was significantly increased in women aged 35-39 years and that risk of difficulties in having a baby increased significantly as soon as the woman was $\geq 30$ years. When maternal and paternal age were considered together, we observed a different age pattern: the risk of delayed pregnancy onset increased in couples composed of a woman aged 35-39 years and of a man aged $\geq 40$ years but not in couples composed of a woman aged 35-39 years and of a man aged $<40$ years. Similarly, the risk of difficulties in having a baby when the woman was aged $30-34$ years was increased only if the man was $\geq 40$ years. Finally, we noted that couples composed of a woman aged 35-39 years and of a man aged $\geq 40$ years had clearly higher risks than other couples as indicated by an OR of $2.99(95 \%$ CI: 1.82, 4.91) for delay in pregnancy onset and an OR of $4.58(2.77,7.55)$ for difficulties in having a baby.

Among couples composed of a woman aged 35-39 years, we observed a mean maternal age of 36.05 years if the man was $<40$ years and of 36.71 years if the man was $\geq 40$ years. We estimated that this small increase in maternal age could not account for the large increase in 
risk when the man was $\geq 40$ years.

Among potential confounders included in models (Table II and Table III), the number of previous pregnancies was significantly associated with delay in pregnancy onset and difficulties in having a baby. Female smoking and history of miscarriage were also risk factors for difficulties in having a baby. ${ }^{12-14}$ 


\section{COMMENT}

Our results obtained from a representative European database provide evidence that paternal age plays a key role in the risk of infertility. Risks were significantly higher if the male partner was aged $\geq 40$ years than if the male partner was aged $<40$ years when the female partner was aged 35-39 years. The effect of paternal age was much less dramatic (and not significant) in couples composed of a woman aged $<35$ years. Similar results were exhibited in a recent study where fecundity (measured by the probability of clinical pregnancy following intercourse on a given day relative to ovulation) decreased with paternal age but only among couples composed of a woman aged 35-39 years. ${ }^{6}$ In this study the probability of pregnancy following intercourse on only the most fertile day decreased for women aged 35 years from 0.29 when the male partner was age 35 years to 0.18 when the male partner was age 40 years. Because maternal age $\geq 35$ years is an important risk factor for infertility, the combined effect of maternal age of $\geq 35$ years and of paternal age of $\geq 40$ years increased markedly the risk of infertility (Table III). The risk of experiencing difficulties in having a baby increased more than the risk of delay in pregnancy onset, which reflects the increased risk of miscarriage with maternal age and paternal age. ${ }^{15}$ By showing a significant paternal age effect only in women aged $\geq 35$ years, these results indicated that major infertility risks may arise principally in couples where both male and female ages are elevated. This conclusion was concordant with results indicating a high risk of infertility when both partners presented reproductive disorders. ${ }^{16}$

In this European study, data were self-reported by women without medical confirmation. Thus, two limitations must be considered: quality of history recall and variability in definition of reproductive issues. Quality of recall of time to pregnancy (TTP) and of pregnancy outcomes has been tested in studies that showed a good concordance 
between retrospectively and prospectively collected data. ${ }^{\mathbf{9 , 1 7}}$ For detection of infertility (defined as a TTP up to 12 months), the retrospective data had a sensitivity of $86.7 \%$ and a specificity of $93.5 \%$ when collected during a personal interview (versus $79.9 \%$ and $94.9 \%$ when collected by a self-completion mailed questionnaire). ${ }^{9}$ In other respects, the European questionnaire was developed and validated (pre-tested) in order to question women by clear specification of reproductive notions (especially TTP). The interviewers were also trained to give clear information on the definition of reproductive issues.

A Medline review of surveys of infertility showed a large variation in the risk of infertility. ${ }^{18}$ It varies highly according to the definition of infertility (usually a delay in pregnancy onset $>$ or $\geq 12$ or 24 months) and to the studied population. For example, in our study, the risk of delay in pregnancy onset varies from $25.4 \%$ when defined as a delay $\geq 12$ months among all couples trying to conceive (regardless of whether the couple did in fact conceive, did not conceive or gave up trying) to $12.4 \%$ when defined as a delay $>12$ months among couples having conceived. Such a level of risk of infertility is concordant with other studies on pregnant women which found a risk of $12 \%{ }^{5}$ It has been shown that analysis of couples having conceived led to marked under-estimation of the risk of infertility, because the studied population excluded less fecund couples who had not yet conceived at the time when the survey was carried out. ${ }^{\mathbf{8}}$ For example, it has been shown that this selection bias could lead to an inverse maternal age effect: in studies based on pregnancy samples, the risk of infertility may appear to decrease as maternal age increases. ${ }^{19}$ To analyze age effect in our study, we thus considered all couples whether they conceived or not, in order to avoid such marked selection bias.

There may be a genetic basis for the effects of age on male fertility, as demonstrated for female fertility. The frequency of genetic diseases due to new autosomal mutations is higher 
in children of fathers aged $\geq 40$ years. ${ }^{11} \mathrm{~A}$ recent study indicated that advanced male age might also lead to an increase in the frequency of numerical and structural aberrations in sperm chromosomes. ${ }^{20}$ The effect of paternal age may also be mediated by semen characteristics which deteriorate as the man ages. ${ }^{\mathbf{2 1 - 2 2}}$

Maternal age of $\geq 35$ years has long been considered an important risk factor for infertility. Our results showed that for these women, the risk of infertility is significantly increased when the male partner is aged $\geq 40$ years. Thus, paternal age $\geq 40$ years should also be considered a key risk factor. Our results may have important implications for couples delaying childbearing and for infertile couples requesting IVF if the woman is $\geq 35$ years of age and the man is $\geq 40$ years of age. 


\section{ACKNOWLEDGMENTS}

The European Study of Infertility and Subfecundity is a European

Community/Cooperation in Scientific and Technical Research (COST) Action Research

Program (contracts MR4/0205/DK and MR4/0343/DK). Additional support was provided by

funds from each participating country. The members of the data collection project

management group were Drs. S. Juul (Denmark), J. Olsen (Denmark), I. Schaumburg

(Denmark), P. Thonneau (France), W. Karmaus (Germany), I. Figá-Talamanca (Italy), L.

Bisanti (Italy), F. Bolúmar (Spain), M. Wulff (Sweden) and T. Fletcher (United Kingdom). 


\section{REFERENCES}

1. Gosden R, Rutherford A. Delayed childbearing. BMJ 1995;311:1585-6.

2. Breart G. Delayed childbearing. Eur J Obstet Gynecol Reprod Biol 1997;75:71-3.

3. Selvin S, Garfinkel J. Paternal age, maternal age and birth order and the risk of a fetal loss. Hum Biol 1976;48:223-30.

4. Ford JH, MacCormac L, Hiller J. PALS (pregnancy and lifestyle study): association between occupational and environmental exposure to chemicals and reproductive outcome. Mutat Res 1994;313:153-64.

5. Ford WC, North K, Taylor H, Farrow A, Hull MG, Golding J. Increasing paternal age is associated with delayed conception in a large population of fertile couples: evidence for declining fecundity in older men. The ALSPAC Study Team (Avon Longitudinal Study of Pregnancy and Childhood). Hum Reprod 2000;15:1703-8.

6. Dunson DB, Colombo B, Baird DD. Changes with age in the level and duration of fertility in the menstrual cycle. Hum Reprod 2002;17:1399-403.

7. Paulson RJ, Milligan RC, Sokol RZ. The lack of influence of age on male fertility. Am J Obstet Gynecol 2001;184:818-22; discussion 822-4.

8. Olsen J, Juul S, Basso O. Measuring time to pregnancy. Methodological issues to consider. Hum Reprod 1998;13:1751-3.

9. Joffe M, Villard L, Li Z, Plowman R, Vessey M. A time to pregnancy questionnaire designed for long term recall: validity in Oxford, England. J Epidemiol Community Health 1995;49:314-9.

10. Baird DD, Wilcox AJ, Weinberg CR. Use of time to pregnancy to study environmental exposures. Am J Epidemiol 1986;124:470-80.

11. Bordson BL, Leonardo VS. The appropriate upper age limit for semen donors: a review of the genetic effects of paternal age. Fertil Steril 1991;56:397-401. 
12. Regan L, Braude PR, Trembath PL. Influence of past reproductive performance on risk of spontaneous abortion. BMJ 1989;299:541-5.

13. Hull MG, North K, Taylor H, Farrow A, Ford WC. Delayed conception and active and passive smoking. The Avon Longitudinal Study of Pregnancy and Childhood Study Team. Fertil Steril 2000;74:725-33.

14. Bolumar F, Olsen J, Boldsen J, European Infertility and Subfecundity Study Group. Smoking reduces fecundity: a European multicenter study on infertility and subfecundity. Am J Epidemiol 1996;143:578-87.

15. La Rochebrochard (de) E, Thonneau P. Paternal age and maternal age are risk factors for miscarriage; results of a multicentre European study. Hum Reprod 2002;17:1649-56.

16. Thonneau P, Marchand S, Tallec A, Ferial ML, Ducot B, Lansac J, et al. Incidence and main causes of infertility in a resident population $(1,850,000)$ of three French regions (1988-1989). Hum Reprod 1991;6:811-6.

17. Wilcox AJ, Horney LF. Accuracy of spontaneous abortion recall. Am J Epidemiol 1984;120:727-33.

18. Schmidt L, Munster K. Infertility, involuntary infecundity, and the seeking of medical advice in industrialized countries 1970-1992: a review of concepts, measurements and results. Hum Reprod 1995;10:1407-18.

19. Juul S, Keiding N, Tvede M, European Infertility and Subfecundity Study Group. Retrospectively sampled time-to-pregnancy data may make age-decreasing fecundity look increasing. Epidemiology 2000;11:717-9.

20. Sartorelli EM, Mazzucatto LF, de Pina-Neto JM. Effect of paternal age on human sperm chromosomes. Fertil Steril 2001;76:1119-23.

21. Eskenazi B, Wyrobek AJ, Sloter E, Kidd SA, Moore L, Young S, et al. The association of age and semen quality in healthy men. Hum Reprod 2003;18:447-454. 
22. Kidd SA, Eskenazi B, Wyrobek AJ. Effects of male age on semen quality and fertility: a review of the literature. Fertil Steril 2001;75:237-48. 
TABLE I. Description of the study population $(n=3287)$

\begin{tabular}{|c|c|c|}
\hline Characteristics & No. & $\%$ \\
\hline \multicolumn{3}{|l|}{ Delay in pregnancy onset } \\
\hline No & 2452 & 74.6 \\
\hline Yes & 835 & 25.4 \\
\hline \multicolumn{3}{|c|}{ Difficulties in having a baby } \\
\hline No & 2354 & 71.6 \\
\hline Yes & 933 & 28.4 \\
\hline \multicolumn{3}{|l|}{ Maternal age } \\
\hline$<30$ years & 2287 & 69.6 \\
\hline $30-34$ years & 771 & 23.4 \\
\hline $35-39$ years & 200 & 6.1 \\
\hline$\geq 40$ years & 29 & 0.9 \\
\hline \multicolumn{3}{|l|}{ Paternal age } \\
\hline$<40$ years & 3101 & 94.3 \\
\hline$\geq 40$ years & 186 & 5.7 \\
\hline \multicolumn{3}{|l|}{ Countries } \\
\hline Denmark & 543 & 16.5 \\
\hline Germany & 862 & 26.2 \\
\hline Italy & 1382 & 42.1 \\
\hline Spain & 500 & 15.2 \\
\hline \multicolumn{3}{|c|}{ Number of previous pregnancies } \\
\hline 0 & 1088 & 33.1 \\
\hline$\geq 1$ & 2199 & 66.9 \\
\hline \multicolumn{3}{|l|}{ Female smoking } \\
\hline No & 1909 & 58.1 \\
\hline Yes & 1378 & 41.9 \\
\hline \multicolumn{3}{|l|}{ Male smoking } \\
\hline No & 1353 & 41.2 \\
\hline Yes & 1934 & 58.8 \\
\hline \multicolumn{3}{|l|}{ Monthly sexual activity } \\
\hline$<5$ & 309 & 11.6 \\
\hline $5-19$ & 1949 & 73.2 \\
\hline$\geq 20$ & 403 & 15.2 \\
\hline \multicolumn{3}{|l|}{ Previous miscarriage } \\
\hline No & 2796 & 85.1 \\
\hline Yes & 491 & 14.9 \\
\hline \multicolumn{3}{|l|}{ Previous induced abortion } \\
\hline No & 3007 & 91.5 \\
\hline Yes & 280 & 8.5 \\
\hline
\end{tabular}


TABLE II. Effect of paternal age on risk of delay in pregnancy onset and of difficulties in having a baby among different maternal age groups

\begin{tabular}{|c|c|c|c|c|c|c|}
\hline \multirow{2}{*}{$\begin{array}{c}\text { Maternal } \\
\text { age }\end{array}$} & \multirow{2}{*}{$\begin{array}{c}\text { Paternal } \\
\text { age }\end{array}$} & \multirow[b]{2}{*}{$n$} & \multicolumn{2}{|c|}{ Delay in pregnancy onset ${ }^{(a)}$} & \multicolumn{2}{|c|}{ Difficulties in having a baby ${ }^{(b)}$} \\
\hline & & & $\%$ & adjusted $O R^{(c)}$ & $\%$ & adjusted $O R^{(c)}$ \\
\hline
\end{tabular}

Men with a female partner aged $<30$ years $(n=2287)$

$<30\left\{\begin{array}{rrrlll}<40 & 2243 & 24.12 & 1.00 & 26.21 & 1.00 \\ \geq 40 & 44 & 27.27 & 1.18(0.60,2.32) & 29.55 & 1.18(0.61,2.28)\end{array}\right.$

Men with a female partner aged 30-34 years $(n=771)$

$30-34\left\{\begin{array}{rrrlll}<40 & 716 & 25.00 & 1.00 & 28.21 & 1.00 \\ \geq 40 & 55 & 29.09 & 1.17(0.63,2.18) & 40.00 & 1.65(0.93,2.93)\end{array}\right.$

Men with a female partner aged 35-39 years $(n=200)$

$35-39\left\{\begin{array}{rrrlll}<40 & 132 & 27.27 & 1.00 & 32.58 & 1.00 \\ \geq 40 & 68 & 45.59 & 2.21(1.13,4.33) & 58.82 & 3.02(1.56,5.85)\end{array}\right.$

Men with a female partner aged $>40$ years $(n=29)$

$\geq 40\left\{\begin{array}{llllll}<40 & 10 & 50.00 & -(d) & 90.00 & -(d) \\ \geq 40 & 19 & 78.95 & & 84.21 & \end{array}\right.$

(a) No conception after 12 months of regular sexual relationship without using a birth control method.

(b) Delay in pregnancy onset (cf. (a)) or having a pregnancy not resulting in a live birth (i.e. ectopic pregnancy, miscarriage or stillbirth).

(c) $\mathrm{OR}=$ odds ratio, the confidence interval is indicated in brackets. Adjusted variables were: country, number of previous pregnancies, female smoking, male smoking, sexual activity, history of miscarriage, history of induced abortion.

(d) The logistic model could not be estimated because of insufficient observations. 
TABLE III. Effect of age on the risk of delay in pregnancy onset and the risk of experiencing difficulties in having a baby when considering paternal age and maternal age $(n=3258)$

\begin{tabular}{|c|c|c|c|}
\hline $\begin{array}{l}\text { Maternal } \\
\text { age } \\
\text { (years) }\end{array}$ & $\begin{array}{l}\text { Paternal } \\
\text { age } \\
\text { (years) }\end{array}$ & $\begin{array}{c}\text { Delay in pregnancy onset }{ }^{(a)} \\
\text { adjusted } O R^{(c)}\end{array}$ & $\begin{array}{c}\text { Difficulties in having a baby }{ }^{(b)} \\
\text { adjusted } O R^{(c)}\end{array}$ \\
\hline
\end{tabular}

Age effect when considering only maternal age

$\begin{array}{rrll}<30 & - & 1.00 & 1.00 \\ 30-34 & - & 1.16(0.96,1.41) & 1.24(1.03,1.49) \\ 35-39 & - & 1.79(1.30,2.46) & 2.22(1.64,3.01)\end{array}$

Age effect when considering only paternal age

$\begin{array}{llll}- & <40 & 1.00 & 1.00 \\ - & \geq 40 & 1.76(1.26,2.45) & 2.30(1.67,3.17)\end{array}$

Age effect when considering maternal age and paternal age

\begin{tabular}{|c|c|c|c|}
\hline \multirow{2}{*}{$<30$} & $<40$ & 1.00 & 1.00 \\
\hline & $\geq 40$ & $1.18(0.60,2.32)$ & $1.17(0.60,2.27)$ \\
\hline \multirow{2}{*}{$30-34$} & $<40$ & $1.15(0.94,1.40)$ & $1.19(0.98,1.45)$ \\
\hline & $\geq 40$ & $1.39(0.76,2.52)$ & $2.00(1.15,3.48)$ \\
\hline \multirow{2}{*}{$35-39$} & $<40$ & $1.34(0.89,2.00)$ & $1.50(1.02,2.20)$ \\
\hline & $\geq 40$ & $2.99(1.82,4.91)$ & $4.58(2.77,7.55)$ \\
\hline
\end{tabular}

(a) No conception after 12 months of regular sexual relationship without using a birth control method.

(b) Delay in pregnancy onset (cf. (a)) or having a pregnancy not resulting in a live birth (i.e. ectopic pregnancy, miscarriage or stillbirth).

(c) $\mathrm{OR}=$ odds ratio, the confidence interval is indicated in brackets. Adjusted variables were: country, number of previous pregnancies, female smoking, male smoking, sexual activity, history of miscarriage, history of induced abortion. 